\title{
THE IMPORTANCE OF PREVENTION AND CONTROL OF CORONOVIRUS DISEASE (COVID-19) IN DENTAL AND ORAL HOSPITAL
}

\author{
M. Ridhatul Aslam, Chriswardani Suryawati, Farid Agushybana \\ Master Program of Public Health Science, Faculty of Public Health Universitas Diponegoro \\ SH Street, Tembalang, Semarang, Central Java 1269, Indonesia
}

\begin{abstract}
Coronavirus has become certain threat toward dental and oral healthcare, therefore Dental and Oral Hospital as healthcare and academic facilities in dentistry should notice to conduct Coronavirus (Covid-19) prevention and control efforts. The article aims to analyze the importance of policies on Coronavirus (Covid19) prevention and control in Dental and Oral Hospital. The Literature Review used in the article was Systematic Literature review method by analyzing 429 arcticles in the search engine of WHO scientific articles related to the key words and obtained 13 articles which were collected as the literature study materials which were related to the theme of the implementation of Coronavirus (Covid-19) prevention and control policies. Based on the result of the study it may get conlcuded that the Management Role of Dental and Oral Hospital as the designer and the instigator of healthcare service and academic activities implementation is very crucial. Commitment of the stakeholders should be performed yet need to consider the guidelines aspect which is suggested and used from various references as well as the central government's policies to apply effective Coronavirus Disease (Covid-19) prevention and control. In the prevention and control related to dentistry academic activities it requires an available smart gadget and application to enable students listening and reviewing lectures at anywhere and anytime possible. Therefore, the implementation of Coronavirus Disease (Covid-19) prevention and control may run effectively and efficiently.
\end{abstract}

Keywords: Covid-19, prevention and control, dentistry, dental and oral hospital

\begin{abstract}
ABSTRAK
Coronavirus menjadi ancaman tersendiri terhadap pelayanan kesehatan gigi dan mulut, untuk itu Rumah Sakit Gigi dan Mulut sebagai tempat pelayanan kesehatan dan pendidikan untuk bidang kedokteran gigi perlu memperhatikan perlu melakukan upaya pencegahan dan pengendalian Coronavirus Disease (Covid-19). Tujuan dari penulisan artikel ini adalah menganalisis pentingnya kebijakan pencegahan dan pengendalian Coronavirus Disease (Covid-19) di Rumah Sakit Gigi dan Mulut. Literatur review dalam artikel ini menggunakan metode Systematic Literatur review dengan menelaah dari 429 artikel di mesin pencarian artikel ilmiah WHO terkait kata kunci dan diperoleh 13 artikel yang dikumpulkan sebagai bahan studi literatur yang berkaitan dengan tema implementasi kebijakan pencegahan dan pengendalian Covid-19. Berdasarkan hasil penelitian dapat menyimpulkan bahwa Peran Manajemen Rumah Sakit Gigi dan Mulut sebagai perancang dan penggerak implementasi kegiatan pelayanan kesehatan dan akademik sangat krusial untuk dilakukan. Komitmen para pemangku kebijakan ini perlu ditunjukkan namun memperhatikan aspek pedoman yang disarankan atau digunakan dari berbagai rujukan literatur maupun kebijakan pusat agar terlaksananya pencegahan dan pengendalian Coronavirus Disease (Covid-19) yang efektif. Dalam pencegahan dan pengendalian terkait dengan kegiatan akademis kedokteran gigi diperlukan sebuah perangkat dan aplikasi cerdas yang ada telah memungkinkan siswa dapat mendengarkan materi kuliah kapanpun dan dimanapun. Dengan demikian pelaksanaan pencegahan dan pengendalian Coronavirus Disease (Covid-19) dapat berjalan secara efektif dan efisien.
\end{abstract}

Kata kunci: Covid-19, pencegahan dan pengendalian, kedokteran gigi, rumah sakit gigi dan mulut

Correspondece Address: Farid Agushybana, Program of Public Health Science, Faculty of Public Health Universitas Diponegoro, SH Street, Tembalang, Semarang, Central Java, Postal Code: 1269, Indonesia, E-mail:agushybana@lecturer.undip.ac.id 


\section{Introduction}

Coronavirus Disease (Covid-19) rapidly spread accros the world, including Indonesia. Since the first case was pulicized on 2 March 2010, Indonesia has been the fourth country with the most cases in South East Asia. However, the highlight is on the figure of $8.13 \%$ of the highest Case Fatality Rate among other South East Asia countries. On 14 May 2020 Indonesia recorded 9,511 positive cases and total deaths at 773 , meanwhile Singapore as the country with the highest positive cases recorded 12 deaths out off 14,951 total positive cases, likewise Philippines and Myanmar also had lower mortality rate than Indonesia. ${ }^{1}$ Therefore, in accordance with the Regulation of the Minister of Health of the Republic of Indonesia Number 1173/MENKES/PER/2004 Concerning Dental and Oral Hospitals the President establishes Coronavirus (Covid 19) as a Public Health Disease through Presidential Decree No. 11 of $2020 .^{2}$

Head of Task Force for Covid-19 Countermeasure Acceleration conveyed that by 6 April 2020 there were a total of 20 doctors who died from coronavirus however not all of them died during their duty on the frontline of the coronavirus battle, some of them were also dentists and otolaryngologists, therefore his team suggested Health Ministry to close the two areas of practice. ${ }^{3}$ The high risk of transmission on medical practice and other healthcare service is in accordance with Healthcare Associated Infection (HAIS) which provides wider definition of infection transmission that does not merely occur in general hospitals setting but also in other healthcare facilities. The infection does not merely occur in patients but also can occur in health workers who perform health care service. ${ }^{4}$

Several case studies show aerosols to be one way of spreading Covid-19. ${ }^{5-6}$ The process of transmitting infections that occur in dental and oral care can be via droplets, aerosols and fomites so that this condition makes dentists and patients very susceptible to contract illnesses especially physical contact which is indeed close during treatment. ${ }^{6}$ This condition needs to be new a concern and a challenge in dentistry to face the threat of Covid-19. ${ }^{7}$

Dental and Oral Hospital is one of healthcare facilities that provides means to improve quality of service, education, research in dental and oral health from the level of basic up to specialist corresponding the public's demands and the development of medical and dentistry science and technology. ${ }^{8}$ Some cases of dental and mouth hospitals have closed their services and academic activities and diverted them online to avoid cases and the spread of Covid-19 in their place. ${ }^{7}$ Therefore, dental and oral health providers should notice infection prevention practices to protect patients' and their own health. WHO Indonesia has released guidelines on prevention and control of Covid-19 infection for healthcare service, hence Indonesian Dental Association or Persatuan Dokter Gigi Indonesia (PDGI) accomodates by making guidelines on prevention and 
control of Covid-19 infection for dental and oral healthcare service through circular letter no. 2776/PB PDGI/III-3/2020. ${ }^{9}$ However some policies and guidelines related to the prevention and control does not yet address in detail the aspects related to management, technical activities of dental and oral healthcare service, and academic activities of dentistry which can become reference during the pandemic.

Based on the explanation above, concerning the prevention and control of Coronavirus Disease (Covid-19) in Dental and Oral Hospital, it requires a policy in order to give inputs and solution for related institutions as well as the others to deal with the pandemi. The article aims to analyze the problems through literature study and explore which factors that can support and obstruct the implementation of prevention and control policy on Coronavirus Disease (Covid-19) in Dental and Oral Hospital.

\section{Method}

\section{Searching for Relevant Studies}

The article was prepared by using literature study technique by collecting data and sources related to the theme and problems to be analyzed. A systematic search strategy was conducted in May 2015 using computerized database from WHO website on Global Literature on Corona Disease by seeking scientific articles. ${ }^{10}$ Search strategies were built based on the keywords, such as health policy, dentistry, coronavirus disease (Covid-19), prevention and control, dental student, dentist and dental oral hospital.

\section{Selection Criteria for All Studies}

The Selection was restricted published after 2000. Through 2 mounting filters: first the screening was done by the first author through titles and abstracts with criteria: (i) related to Covid19, (ii) related to dentistry. Entering the second stage, re-filtering was carried out through complete articles and approved by the second and third authors.

\section{Data Extraction and Synthesis}

From the scientific articles that have been collected, an analysis and evaluation of various research results and literature on the purpose of the articles were conducted. The following results were extracted: The importance of making dental and oral care protocols in a pandemic condition, delaying/dismissing academic activities, and the role of dental and oral hospital management (Table 1). 


\section{Results}

\section{Literature Searching and Article Appropriateness}

Figure 1 presents a flow chart of literature selection procedure. The systematic literature search yielded 429 articles, after the screening process 13 articles were selected as literature study material related to the implementation of Covid-19 prevention and control policies. The articles were analyzed for their appropriateness as able to give inputs and information directly related to the theme of discussion.

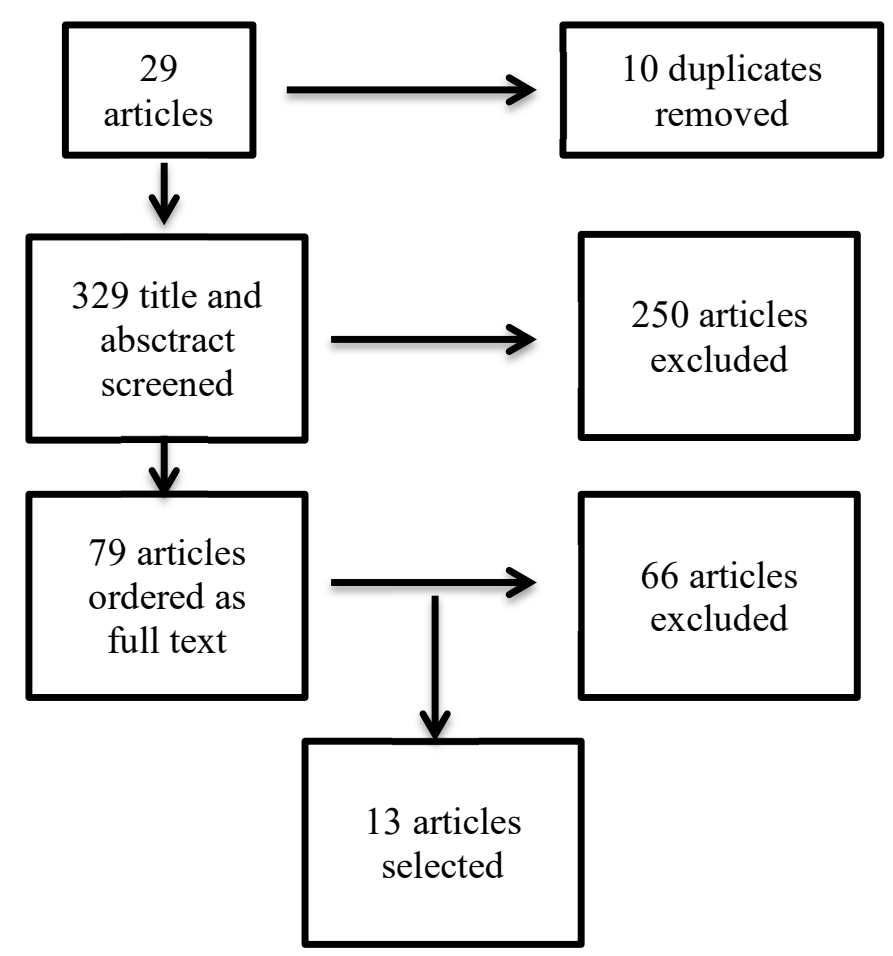

Figure 1. Flow chart: selection of the literature

\section{Main Findings}

Table 1 presents the main findings of each article. They were analyzed then concluded for the main objective points out of the 13 articles, subsequently 3 points were found, namely the importance of making dental and oral care protocols in a pandemic condition, delaying or dismissing the activities of dental and oral services as well as academics, and the role of dental and oral hospital management. 
Table 1.

Policies on Prevention and Control (Covid-19)

\begin{tabular}{|c|c|c|c|}
\hline Authors & $\begin{array}{l}\text { Types of the } \\
\text { Study }\end{array}$ & Subjects of the Study & Main Findings \\
\hline L. Meng et al & Case Report & $\begin{array}{l}\text { Hospital and School of } \\
\text { Stomatology Wuhan } \\
\text { University }\end{array}$ & $\begin{array}{l}\text { Virology, Infection Control } \\
\text { Dental Public Health, Dental Education, } \\
\text { Transmission, Dental Practice } \\
\text { Management }^{7}\end{array}$ \\
\hline Soyoung Kim et al & $\begin{array}{l}\text { Quasi } \\
\text { Experiment }\end{array}$ & $\begin{array}{l}\text { Child and Adult Group from } \\
\text { The Case Data Report of } \\
\text { Center for Infection } \\
\text { Prevention and Control } \\
\text { Network }\end{array}$ & $\begin{array}{l}\text { COVID-19, Mathematical Modeling, } \\
\text { Behavioral Change, School Opening } \\
\text { Postponement, School Closing }\end{array}$ \\
\hline Yousef Khader et al & Quantitative & $\begin{array}{l}\text { Dentists Who Worked in } \\
\text { Jordan }\end{array}$ & $\begin{array}{l}\text { COVID-19, Infection } \\
\text { Dentists, Infection Control }{ }^{12}\end{array}$ \\
\hline Paul Coulthard & $\begin{array}{l}\text { Opinion } \\
\text { Research }\end{array}$ & Dentistry \& Coronavirus & $\begin{array}{l}\text { Dental and Oral Examination During } \\
\text { Coronavirus Global Pandemic } \\
\text { Reasons to Close Dentistry School in } \\
\text { During Coronavirus Global Pandemic } \\
\text { Arguing the Moral Status of Clinical } \\
\text { Dentistry } \\
\text { Health Workers In Balancing Between } \\
\text { Patients' Heathcare And Personal Well- } \\
\text { Being }\end{array}$ \\
\hline Burhan & Case Report & $\begin{array}{l}\text { Covid-19 Mortality Rate } \\
\text { Hospital }\end{array}$ & COVID-19, Infection ${ }^{14}$ \\
\hline Djsari & Case Report & $\begin{array}{l}\text { WHO Press Release } \\
\text { WHO }\end{array}$ & $\begin{array}{l}\text { COVID-19, } \\
\text { Formulation and Implementation of } \\
\text { Clinical Guidelines } \\
\text { Service Quality Management }{ }^{15}\end{array}$ \\
\hline Morfi et al & Review & Hospital & COVID-19 16 \\
\hline Spagnuolo et al & Case Report & Seafood Market in Wuhan & COVID-19, Infection, Coronavirus ${ }^{17}$ \\
\hline Adhikari et al & Review & Publcation & $\begin{array}{l}\text { COVID-19, Epidemiology } \\
\text { Causes, Prevention and Control, } \\
\text { Review }^{18}\end{array}$ \\
\hline Kadam et al & $\begin{array}{l}\text { Quasi } \\
\text { Experiment }\end{array}$ & Dentists & $\begin{array}{l}\text { COVID-19, Coronavirus, } \\
\text { Dentists, SARS-Cov-2, Infection } \\
\text { Control }^{19}\end{array}$ \\
\hline J. Wong et al & Case Report & $\begin{array}{l}\text { Hospital } \\
\text { Operating Room } \\
\text { Staff }\end{array}$ & $\begin{array}{l}\text { COVID-19 } \\
\text { Prevention } \\
\text { Infection }^{20} \\
\text { Virus Corona }\end{array}$ \\
\hline Ather et al & Case Report & $\begin{array}{l}\text { Dental Professionals } \\
\text { Patients }\end{array}$ & $\begin{array}{l}\text { COVID-19; } \\
\text { Dental; } \\
\text { Endodontic; } \\
\text { Severe acute Respiratory Syndrome } \\
\text { Coronavirus } 2 \\
\text { SARS-Cov-2 } \\
\text { Hospital }^{21} \\
\end{array}$ \\
\hline Cheng et al & $\begin{array}{l}\text { Quasi } \\
\text { Experiment }\end{array}$ & $\begin{array}{l}\text { Participants of All Patients } \\
\text { Who Were Consecutively } \\
\text { With COVID-19, } \\
\text { Hospitalized at Tongji } \\
\text { Hospital, Tongji } \\
\text { Medical College, Huazhong } \\
\text { Science and Technology } \\
\text { University }\end{array}$ & $\begin{array}{l}\text { Patients } \\
\text { Mortality from Accute Kidney }{ }^{22}\end{array}$ \\
\hline
\end{tabular}




\section{Systematic Analysis of Main Objective Literatures}

Table 2 displays which articles discuss points that match the main objectives that have been found.

Table 2.

Main Objective Literatures

\begin{tabular}{lccc}
\hline \multicolumn{1}{c}{ Authors } & \multicolumn{3}{c}{ Main Objective } \\
\cline { 2 - 4 } & $\begin{array}{c}\text { The need for dental and } \\
\text { oral care protocols in a } \\
\text { pandemic condition }\end{array}$ & $\begin{array}{c}\text { Delaying / dismissing the } \\
\text { activities of dental and } \\
\text { oral services as well as } \\
\text { academics }\end{array}$ & $\begin{array}{c}\text { The role of dental and } \\
\text { oral hospital } \\
\text { management. }\end{array}$ \\
\hline L. Meng et al & $\checkmark$ & $\checkmark$ & $\checkmark$ \\
Soyoung Kim et al & - & - & - \\
Yousef Khader et al & $\checkmark$ & $\checkmark$ & $\checkmark$ \\
Paul Coulthard & $\checkmark$ & - & - \\
Burhan & - & - & - \\
Djsari & - & - & - \\
Morfi et al & - & - & - \\
Spagnuolo et al & $\checkmark$ & - & - \\
Adhikari et al & - & - & $\checkmark$ \\
Kadam et al & $\checkmark$ & - & - \\
J. Wong et al & - & - & - \\
Ather et al & $\checkmark$ & - & - \\
Cheng et al & - & & - \\
\hline Checklist $(\checkmark)$ if the & & & \\
\hline
\end{tabular}

*Checklist $(\checkmark)$ if the article discusses the main objective

Most of the articles discussed the importance of infection prevention and control protocols during the Covid-19 pandemic, , $72,13,17,19,21$ then the consideration of delaying/dismissing dental and oral health services needs to be considered until the protocol has been established and case situations start to decline $e^{7,12,13}$ and key it all depends on the regulations and policies of stakeholders, especially management in the dental and mouth hospital. ${ }^{7,12,13,19,21}$

\section{Discussion}

The number of Covid-19 cases rapidly increases and it has spreaded across countries. Covid19 human to human transmission turns into the main transmission hence it becomes more agressive. To overcome the widespread ongoing transmission, WHO released guidelines to conduct Physical Distancing which limits space and activities in massive scale including closing the academic activities to slow down and reduce virus transmission. ${ }^{23}$

Dental and oral hospitals perform two main functions namely as healthcare center and educational center. It requires this type of hospitals to integrate two typologies of healthcare and academic buildings into one building which is synergetic in accordance with the two main functions. The Law no. 36 year 2009 concerning Health in article 54 clause 1 mentions Healthcare management and service should be responsible, safe and excellent, equal and non-discriminative. As a part of healthcare facilities, Dental and Oral Hospital is required to implement efforts in preventing infection transmission to patients and health workers in order to ensure health security. ${ }^{24}$ 
The suppression of the spread of Covid-19 Virus which has changed the living system globally, has put many parties in charge, making a policy for educational institutions. This policy with the dismissal of the teaching and learning process which was then replaced with the implementation of distance learning or online learning.

Through the literature study process of various scientific documents and government policies, the aim of this research is to get an overview of the implementation of the Coronavirus Disease (Covid-19) prevention and control policy at the Dental and Oral Hospital. As well as outlining the problem to produce input for the policy.

One area in Indonesia that is experiencing global impact due to the rise of the Covid-19 pandemic is the field of dental and oral health services. The policy taken regarding the prevention and control of this virus is stipulated in Law Number 36 Year $2009,{ }^{24}$ in accordance with this policy RSGM must make efforts to improve prevention of patients and health workers in an effort to ensure health security. The consideration efforts can be made by conducting health quarantine. Delivering information about health protection against emergencies, this will be conveyed by the central and regional governments. The taking of this budget as a form of conflicting spread of the Covid-19 virus in Indonesia has continued to increase in the positive patient ratio of Covid-19 and has also become a global pandemic.

The implementation of health system with medical workers' and hospitals' readiness as its backbone is important. It covers Covid-19 monitoring, prevention, and curative treatment activities, and it is reflected in the clear vision and definite action on detection, cases confirmation and alleged close contact, and intensive care for positive cases. In addition, mutual efforts of crosssectors and various levels in tracing contacts of people under surveillance, implementation of isolation for cases of suspected reactive, with isolation room prepared for those who just came back from abroad or places with red-zone status for 14 days, help to minimize the transmission risk in community. ${ }^{25}$

In one of the studies, it is revealed that in Indonesia there is an association between healthcare service utilization with information of existence, quality of service and healthcare facilities. ${ }^{26}$ Dental dan Oral Hospital is the leading dental and oral healthcare facility in Indonesia that is responsible in organizing public dental and oral healthcare service, also as dental healthcare provider to restore patients' oral health to a better lebel to meet patients satisfaction. ${ }^{27-28}$ Being reviewed from healthcare system in Indonesia, the role of dental and oral hospital is as the vanguard of the healthcare system, ${ }^{29}$ therefore healthcare service is an important factor of health yet it is not the most important, the utilization of provided and optimal healthcare service is an important means to improve one's health status. ${ }^{30}$ The existence of coronavirus is an enormous threat for the community including in term of healthcare service and academic activities. The importance of prevention and control information through policies and guidelines will help in 
surpressing the widespread of virus transmission. Dental and oral healthcare service is closely related to the occurence of cross infection that the protocol of infection prevention and control implementation is extremely crucial. ${ }^{29}$

The Covid-19 Threat Virus can revive all people, especially medical staff such as doctors as the frontline in the eradication of Covid-19. When medical equipment used by doctors or medical personnel has been contaminated by the Covid-19 virus or when carrying out medical examinations on patients, the possibility of a potential doctor can be infected with this virus is quite large. Therefore, dentists should be equipped with Covid-19 related information to minimize the transmission. Diseases may enter through various slits, even for those with excellent antibody. It is not impossible for the dentist to be susceptible from contracted the virus since they make direct contacts with respiratory tracts.

In the aspect of dental and oral care, even though dentists are very knowledgeable in considering the risk of infection transmission. However, in the case of Covid-19 it must be made more stringent and effective because there is a possibility for the patient without any symptoms to be a threat in dental and oral healthcare. Understanding and implementing the guidelines from various literatures including the main guidelines from WHO regarding approval and supervision in health facilities does need to be considered, starting from the initial treatment procedure to completion and evaluation of the patient.

The policies issued by stakeholders, information from various literature and guidelines from the government or organization above can be a reference in the implementation of Covid-19 prevention and control.

The COVID-19 pandemic, which is increasingly spreading over various circles, has disrupted various activities in the community, including academic activities in the Dental and Oral Hospital. Amid the increasingly worrisome conditions, it became a strong reason for the government to issue various policies so that all teaching and learning activities are carried out from home by utilizing technological devices. The utilization of learning technology enables to conduct the learning activities online, this can replace the reguler learning activities that are usually carried out face to face. In addition, students' health and psychology monitoring is also conducted during the pandemic.

Conducting teaching and learning activities online or closing the academic activities that are usually done face to face are able to help in reducing the case of Covid-19. Students spend more time at school during school activities, it turns the school into a potential place of student to student transmission of the Covid-19 cases. The quarantine strategy by the government and public cooperation to carry out social distancing will reduce the Covid-19 cases. However, there are still some people who crowd around in close contact. 
If the school opening is conducted hence the transmission among child group is increasing. The other transmission level will not be increasing and all individuals who are susceptible change their behavior to reduce the transmission by putting on masks and improving personal hygiene. In fact, the other transmission risk factors may get increased after school opening. ${ }^{31}$ First, it is possible to increase the level of contact between students and teachers and level of contact among teachers themselves. It is difficult for the students to maintain their personal hygiene when they are at school. Young age group is not aware enough toward Covid-19 and teachers may loosen their guidance for all students. After one student is confirmed, the student-to-student transmission will occur rapidly. ${ }^{31}$

There are several recommendations for dental and oral education during corona pandemic, among others is adopting online lectures, case studies and case-based learning tutorial to avoid the unnecessary aggression of people and infection-related risks. ${ }^{29}$ The available smart gadgets and applications has enabled students to listen and review the lectures at anywhere and anytime. The fact is that students in Indonesia have been learning from home since 23 March 2020. Second, it requires advocacy to encourage students to get involved in independent learning, fully utilizing online resources, and learn the most current academic updates. The third, during this period, it is easy for the students to get influenced by fear related to the disease and stress, and the dental school should be prepared in giving psychological support for those who need it. ${ }^{32}$

\section{Conclusion}

Main objective of several articles is that the Covid-19 prevention and control protocol is indispensable. The tendency and high risk of dentists in being exposed to Covid-19 need special attention from various related parties to overcome them. Several cases in the literature show the importance of prevention and control in dental and oral health services and academic activities.

The role of Dental and Oral Hospital Management as the designer and the instigator of healthcare service and academic activities is very crucial. Commitment of the stakeholders should be performed yet need to consider the guidelines aspect which is suggested and used from various references as well as the central government's policies to apply effective Coronavirus Disease (Covid-19) prevention and control.

\section{Recommendation}

COVID-19 transmission that is spreaded through direct contact may get prevented by performing prevention and control actions in the service and activities implementation of dental and oral field. Further, it requires to ensure the availability and adequacy of medical and non medical personal protective equipment for regular service in Dental and Oral Hospital. Ensure that the health workers on duty in dealing with Covid-19 get adequate nutritional intake and supplement 
for body immune.

\section{Acknowledgment}

The author would like to send his gratitude toward Ms. Chriswardani Suryawati, the Head of Public Health Science Master study program, and Mr. Farid Agushybana, as his thesis promotors, for their guidance in the arrangement process of this article.

\section{Funding}

The study and arrangement process of this article were self-funded and not granted by any party.

\section{Conflict of Interest}

The authors of this article declare that they are not affiliated with or involved in any organization or entity with any financial or non-financial interest in the subject matter discussed in this article.

\section{REFERENCE}

1. Worldometers. COVID-19 Coronavirus Pandemic [Internet]. Worldometers. 2020 [cited 2020 Apr 6]. Available from:

https:/www.worldometers.info/coronavirus/?utm_campaign=homeAdUOA?Si

2. The President of the Republic of Indonesia. Presidential Decree Number 11 of 2020 on the Declaration of COVID-19 as Public Health Emergency. 2020.

3. Ruqoyah S, Ambarita E. 20 dokter meninggal karena Corona, kebanyakan dokter gigi dan THT [Internet]. VIVAnews. 2020 [cited 2020 Apr 6]. Available from: https://www.vivanews.com/berita/nasional/44119-20-dokter-meninggal-karena-coronakebanyakan-dokter-gigi-dan-tht?medium=autonext

4. JEL H. Case Fatality Rate (CFR) Pandemi (COVID-19) Di Negara-Negara Se-Asia Tenggara [Internet]. Kompasiana. 2020 [cited 2020 May 6]. Available from: https://www.kompasiana.com/herlinajelmatury/5eb2608f097f363277710e52/case-fatalityrate-cfr-pandemi-covid-19-di-negara-negara-asia-tenggara

5. Susilo A, Rumende CM, Pitoyo CW, Santoso WD, Yulianti M, Herikurniawan, et al. Coronavirus disease 2019: Tinjauan literatur terkini. Jurnal Penyakit Dalam Indonesia. 2020;7(1):45-67.

6. Ge Z-Y, Yang L-M, Xia J-J, Fu X-H, Zhang Y-Z. Possible aerosol transmission of COVID19 and special precautions in dentistry. Journal of Zhejiang University-SCIENCE B. 
$2020 ; 21: 361-8$.

7. Meng L, Hua F, Bian Z. Coronavirus disease 2019 (COVID-19): Emerging and future challenges for dental and oral medicine. Journal of Dental Research. 2020;99(5):481-7.

8. The Ministry of Health of the Republic of Indonesia. Regulation of the Minister of Health of the Republic of Indonesia Number No. 1173/Menkes/Per/2004 on Dental and Oral Hospitals. 2004.

9. Indonesian Dental Association. Circular Letter No. 2776/PB PDGI/II-3/2020 on Guidelines for Dentistry Services During the COVID-19 Virus Pandemic. 2020.

10. World Health Organization. Global Literature on Coronavirus Disease [Internet]. World Health Organization. 2019 [cited 2020 Apr 6]. Available from: https://search.bvsalud.org/global-literature-on-novel-coronavirus-2019-ncov/.

11. Kim S, Kim Y-J, Peck KR, Jung E. School opening delay effect on transmission dynamics of Coronavirus disease 2019 in Korea: Based on mathematical modeling and simulation study. Journal of Korean Medical Science. 2020;35(13):1-9.

12. Khader YS, Nsour M Al, Al-Batayneh OB, Saadeh R, Bashier H, Alfaqih M, et al. Dentists' awareness, perception, and attitude regarding COVID-19 and infection Control: Crosssectional study among Jordanian dentists. JMIR Public Health and Surveillance. 2020;6(2).

13. Coulthard P. Dentistry and Coronavirus (COVID-19)-Moral decision-making. British Dental Journal. 2020;228:503-5.

14. Burhan E. Coronavirus yang meresahkan dunia. Journal Of The Indonesian Medical Association. 2020;70(2):1-3.

15. Djasri H. Corona virus dan manajemen mutu pelayanan klinis di rumah sakit. Journal of Hospital Accreditation. 2020;2(1):1-2.

16. Morfi CW, Junaidi A, Elsesmita, Asrini DN, Pangestu F, Lestari DM, et al. Kajian terkini Coronavirus disease 2019 (COVID-19). Jurnal Ilmu Kesehatan Indonesia. 2020;1(1):1-8.

17. Spagnuolo G, Vito D De, Rengo S, Tatullo M. COVID-19 outbreak: An overview on dentistry. International Journal of Environmental Research and Public Health. 2020;17(6):1-3.

18. Adhikari SP, Meng S, Wu Y-J, Mao Y-P, Ye R-X, Wang Q-Z, et al. Epidemiology, causes, clinical manifestation and diagnosis, prevention and control of Coronavirus disease (COVID-19) during the early outbreak period: A scoping review. Infectious Diseases of Poverty. 2020;9(29):1-12.

19. Kadam A, Karjodkar F, Sansare K, Vinay V. COVID 19-Facts and its infection control measures for dentists. IOSR Journal of Dental and Medical Sciences. 2020;19(4):43-52.

20. Wong J, Goh QY, Tan Z, Lie SA, Tay YC, Ng SY, et al. Preparing for a COVID-19 pandemic: A review of operating room outbreak response measures in a large tertiary 
hospital in Singapore. Canadian Journal of Anesthesia. 2020;1-14.

21. Ather A, Patel B, Ruparel NB, Diogenes A, Hargreaves KM. Coronavirus disease 19 (COVID-19): Implications for clinical dental care. J Endod. 2020;46(5):584-95.

22. Cheng Y, Luo R, Wang K, Zhang M, Wang Z, Dong L, et al. Kidney disease is associated with in-hospital death of patients with COVID-19. Kidney International. 2020;97(5):82938 .

23. World Health Organization. Coronavirus Disease (COVID-19) Pandemic [Internet]. World Health Organization. 2020 [cited 2020 Apr 6]. Available from: https://www.who.int/emergencies/diseases/novel-coronavirus-2019

24. Indonesian Forum of Parliamentarians on Population and Development. Law Number 36 of 2009 on Health. 2009.

25. Engkus, Suparman N, Sakti FT, Anwar HS. COVID-19: Kebijakan mitigasi penyebaran dan dampak sosial ekonomi di Indonesia. LP2M. 2020;1-13.

26. Barmo S, Balqis, Nurhayani. Hubungan faktor perilaku konsumen terhadap pemanfaatan pelayanan kesehatan gigi dan mulut di Puskesmas Antang Perumnas Kota Makassar tahun 2013. Jurnal Media Kesehatan Masyarakat Indonesia. 2013;1-12.

27. Patel JY. A study on evaluation of patient satisfaction with dental health care services. International Journal of Scientific and Research Publications. 2014;4(8):466-9.

28. Akbar FH, Awang AH, Hussain MY, Siampa FA, Pratiwi R. Persepsi pasien tentang pelayanan kesehatan gigi dan mulut: Studi kasus di RSGM Halimah DG Sikati Kandea Makassar. In: Nur H, et al., editors. Proceedings of the 1th Academic Symposium on Integrating Knowledge (ASIK) 2019. Johor: Ibnu Sina Institutes for Fundamenal Science Studies, Universiti Teknologi Malaysia; 2014. p. 213-22.

29. Mastaki JK. Utilization of dental health service by adult immigrants: A narrative review. African Journal of Dentistry. 2014;3(1):28-31.

30. Patil NG, Yan YCH. SARS and its effect on medical education in Hong Kong. Medical Education. 2003;37(1):1127-8.

31. Chu HY, Kuypers J, Renaud C, Wald A, Martin E, Fairchok M, et al. Molecular epidemiology of respiratory syncytial virus transmission in childcare. Journal of Clinical Virology. 2013;57(4):343-50.

32. Wong JGWS, Cheung EPT, Cheung V, Cheung C, Chan MTY, Chua SE, et al. Psychological responses to the SARS outbreak in healthcare students in Hong Kong. Medical Teacher. 2004;26(7):657-63. 